\title{
The Effect of ERP Successful Implementation on Employees' Productivity, Service Quality and Innovation: An Empirical Study in Telecommunication Sector in Jordan
}

\author{
Fadi Taher Qutaishat ${ }^{1}$, Shadi Ahmed Khattab ${ }^{1}$, Mohammed Khair Saleem Abu Zaid ${ }^{2}$ \& Excimirey Amer \\ Al-Manasra ${ }^{2}$ \\ ${ }^{1}$ Department of Management Information Systems, Al-Balqa' Applied Univesity, Al-Salt, Jordan \\ ${ }^{2}$ Department of Management \& Marketing, Al-Balqa' Applied Univesity, Al-Salt, Jordan \\ Correspondence: Fadi Taher Qutaishat, Department of Managament Information Systems, Al-Balqa' Applied \\ Univesity, Al-Salt, Jordan. Tel: 962-795-555-834. E-mail: fadi_qutaishat@bea.edu.jo
}

Received: July 19, 2012 Accepted: August 21, 2012 Online Published: October 1, 2012

doi:10.5539/ijbm.v7n19p45 URL: http://dx.doi.org/10.5539/ijbm.v7n19p45

\begin{abstract}
The aim of this research paper is to identify the effect of ERP successful implementation on employees' productivity, service quality and innovation. Data were collected via questionnaires from 129 employees working in the Jordanian telecommunication organizations. The collected data were analyzed using descriptive statistics and structural equation model to test the study hypotheses using AMOS 16.0. The results of this study revealed that there is a significant effect of organizational impact on employees' productivity, service quality and innovation. Whereas, satisfaction only affects the service quality and innovation of employees leaving the employee's productivity surprisingly not affected. This result is very likely due to the lack of suitable training. Therefore, one important recommendation is to develop a training course that identifies and explains to employees all the necessary changes that will occur to the business processes inside the organization as a result of the ERP implementation.
\end{abstract}

Keywords: ERP successful implementation, employees' productivity, service quality, employees' innovation, telecommunication organizations, Jordan

\section{Introduction}

\subsection{Context and the Research Problem}

Today's business operates in a rival and competitive environment. The exponential growth and advancement in IT (information technology) is a significant factor that influence today's business environment. This of course, has made a rival competition among organizations. Therefore, if organizations wish to remain successful and to be competitive, managers need to employ technologies for the benefit of their organizations. This in turn helps organizations improve information flow, reduce costs and streamline business, offer product variety, establish linkage with suppliers and reduce response time to customer needs and expectations (Yoo, Vonderembse \& Ragu-Nathan, 2011; Alavi \& Leidner, 2001).

Organizations may be composed of different dispersed units that require integration. Therefore, managers can focus on ICT (information and communication technologies) to integrate information and communication across units of an organization. Currently, a popular approach to the development of an integrated enterprise-wide system is the implementation of an enterprise resource planning (ERP) system (Beheshti, 2006).

Many challenges are facing organizations; These challenges (such as ease in international trade barriers, economic liberalization, globalization and privatization) have made a heavy burden on organizations specifically in developing countries (which is the case of Jordan) to survive in such environment. This of course has increased the pressure on these organizations to come up with effective and competitive capabilities to survive and succeed. Enterprise resource planning (ERP) is often considered as one of the solutions for organizations to survive (Rao, 2000). ERP systems can successfully integrate the processes of each department, decrease costs, improve effectiveness, increase clients' level of satisfaction and immediately share information with the whole enterprise (Davenport et al, 1998). 
However, a significant aspect for developing an ERP system is to evaluate and measure its performance. This can be achieved by constructing a process for determining the relationships between the objectives of the ERP implementation project and the ERP performance indicators for measuring its performance (Mashari et al., 2003). Evaluating the impact of ERP implementation helps in analyzing the contribution of ERP systems to organizations. Many Jordanian organizations (who implemented ERP systems) do not realize whether the use and deployment of an ERP system enhances their employees' productivity, service quality and innovation.

As mentioned by (McNurlin \& Sprague, 2006) that the mission of the information systems in organizations nowadays has expanded to improve the performance of its employees through the use of IT. Furthermore, Molla and Bhalla (2006) mentioned that despite the expansion of ERP implementation in developing countries, yet there are failures and difficulties facing the implementation of ERP systems. Based on this context, this research provides an excellent opportunity for researchers and practitioners to understand and resolve some of the important issues associated with the use and implementation of ERP systems specifically in Jordanian organizations and generally in organizations in developing countries who are experiencing similar context and situations.

Based on the above, this study investigated the level of ERP implementation and its effect on employees' productivity, service quality and innovation in Jordanian telecommunication organizations.

\subsection{Literature Review}

Organizations, in the current information age, are faced with the challenge of making their different types of systems work together and of seamlessly exchanging information across these systems. One solution to this problem is to implement enterprise applications. These systems enable organizations to integrate, execute and coordinate business processes across the entire organization including all levels of management allowing organizations to become more flexible and productive (Laudon \& Laudon, 2012).

There are four major types of enterprise applications including: enterprise systems, supply chain management systems, customer relationship management systems and knowledge management systems. Enterprise systems (the focus of this research) are also referred to as enterprise resource planning (ERP) systems. ERP systems are being used in organizations to integrate their functional business processes (manufacturing and production, finance and accounting, sales and marketing and human resources), that have been implemented as scattered systems, into a single software system. This system facilitates the integration of information by utilizing a central data repository allowing effective use of information by different parts within an organization (Laudon \& Laudon, 2012; Botta-Genoulaz \& Millet, 2006).

ERP systems can be defined as integrated software package composed of set of standard functional modules such as production, sales, human resources, finance, etc., which can be adapted to the specific needs of each organization (Nah \& Lau, 2001 ;Botta-Genoulaz \& Millet, 2006; Doom, et al., 2009).

Currently, ERP systems are the most rapidly growing systems in organization. ERP systems have emerged as a response to the enormous transformation in businesses caused by clients' demand of fast services, wider choices and lower prices. Other factors such as globalization, the need for process standardization and the highly changeable expectations of customers, have also participated in business transformation. ERP systems have been employed in both large and small-medium organizations because of these systems abilities to efficiently respond to these challenges (Botta-Genoulaz \& Millet 2006, p. 204; Jacobson, et al., 2007). This of course, has drawn organizations' attention to invest in ERP systems. According to Jacobson, et al. (2007), ERP revenues grew to over \$28 Billion in 2006 and it continued to grow with an estimate of 47.7 Billion in 2011. Implementing ERP systems allows organizations to achieve many benefits including the availability of integrated information, high responsiveness to customers' and suppliers' needs and the provision of timely information to decision makers. Another key benefit of ERP systems is the integration of information throughout the supply chain which leads to cost and inventory reductions and improved operating performance. This of course excels the performance of the functional areas within organizations. For instance, in sales, increased efficiency leads to satisfy customers through providing lower quotes and increased responsiveness. In service, accessible data on customers' services history in addition to (e.g. warranty information) leads to improved interaction with customers. Therefore, it can be noted that implementing ERP systems elevates and improves the performance of organizations. Form a technical perspective, ERP systems provides many advantages. For example, all information can be allocated in a central place that is ready for being accessed and shared by the functional departments. This eliminates the need for legacy systems that maintain incompatible and fragmented data (sumner, 2005). 
However, implementing ERP systems require considerable time and cost, and it may take time before realizing the benefits of investment in ERP systems (sumner, 2005). Botta-Genoulaz \& Millet (2006) stated that ERP projects showed difficulties and even failure in implementation. The expected outcomes of ERP projects were rarely reached and costs were over budgeted. Davenport (2000), discussed the two reasons that leads to this failure: first, the technical complexity associated with the implementation process of ERP which requires a great deal of expertise. Second, the mismatch between the technical specifications of the ERP system and the business requirements of the organization.

\subsubsection{ERP Successful Implementation}

Dezdar \& Sulaiman (2009) found that that organizational impact and user satisfaction were the two most frequently used measures for ERP implementation. The user's satisfaction can be defined as those feelings and attitudes towards a variety of factors related to the delivery of information products and services, including being up-to-date, being precise, being comprehensive and so forth (Dezdar \& Sulaiman, 2011). The other variable i.e. ERP organizational impacts relates to the effect of ERP system implementation and usage on the performance of the organization. Organizational impact refers to the realization of business goals and improved enterprise operating capabilities as a result of the ERP implementation. The perceived organizational impact variable covers both effectiveness and efficiency-based performance improvements in order to capture the business benefits of the ERP system (Stratman \& Roth, 2002).

\subsubsection{Productivity}

Employee productivity is a particularly important issue to managers and supervisors as the primary purpose of their job is to get the most out of the people they are responsible for. Caruso (2009) the founder of David Caruso \& Associates Inc., stated that employees are the secret of the success of any manufacturing industry. In today's cost-competitive world, the emphasis is on getting things done through increasing the productivity of employees. Empowering employees by giving them timely information boosts productivity, and this can be done by using an integrated technology such as enterprise resource planning system (ERP). Nurmilaakso (2009) stated that one of the reasons behind investing in ICT solutions is to improve labor productivity, where the ERP system has a positive influence on labor productivity.

\subsubsection{Service Quality}

Quality has been typically regarded as a key strategic component of competitive advantage and the enhancement of service and product quality in organizations and still until present (Soltani et al., 2011; Li et al., 2011). According Bosschaa et al., (2006) many factors causes poor product quality in small manufacturing companies that cannot afford advanced management systems such as: problem allocation delays and intervention, poor human resource allocation and poor inventory management. Mjema et al., (2005) showed that the introduction of IT in quality management had contributed greatly to the enhancement of quality awareness towards the improvement of services and products and in the reduction of quality costs.

\subsubsection{Innovation}

Kanter (1988) defined innovation as the creation and exploitation of new ideas. Innovation is being increasingly seen as a critical competitive advantage and has been recognized as an important trend (Barsh, 2007); Chapman \& Hyland (2004); Hamel \& Prahalad (1991)). Innovation is often characterized as a type of organizational capital and has been broadly defined as an idea, a product or process, system or device that is perceived to be new to an individual, a firms, an industrial sector or a society as a whole (Rogers, 1995). Research relating to the use of IT in managing innovation remains sparse, with an exception of researchers such as Cooper (2003), who provide an outline of the practitioner experience with existing tools used in new product development processes. Organizations that use the best technologies are not always the most profitable firms or the ones with the largest market shares, since there are other factor that plays a major role in determining the degree of innovativeness in an organization such as the size and the profit of the organization.

\subsection{The Research Model and Hypotheses}

Figure 1 shows the components of the research model including the ERP implementation the independent variable (organizational impact and satisfaction). In addition, the figure shows the employee's productivity, service quality and innovation as the study's dependent variables. 


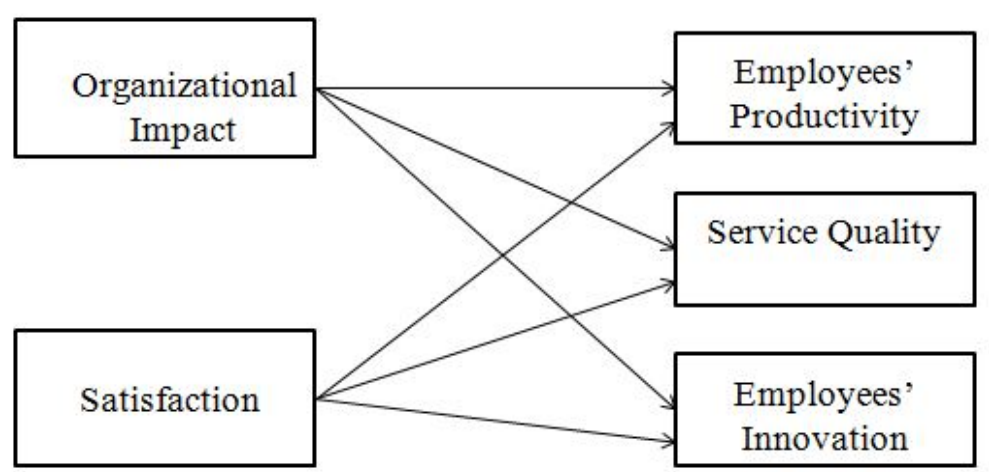

Figure 1. The research model (adapted by author, 2012)

Based on the research model, the following hypotheses were formulated:

Hypothesis 1: There is a significant effect of ERP organizational impact on employees' productivity.

Hypothesis 2: There is a significant effect of ERP organizational impact on service quality.

Hypothesis 3: There is a significant effect of ERP organizational impact on employees' innovation.

Hypothesis 4: There is a significant effect of ERP user's satisfaction on employees' productivity.

Hypothesis 5: There is a significant effect of ERP user's satisfaction on service quality.

Hypothesis 6: There is a significant effect of ERP user's satisfaction on employees' innovation.

\section{The Research Method}

\subsection{Sample}

A total of 300 questionnaires were distributed on employees (actual users of ERP systems) working in telecommunication organizations: Zain, Umnia and Orange. Purposive sampling technique was used to select respondents from the population of the study. The response rate was $43 \%$; table 1 shows the sample characteristics.

Table 1. The main characteristics of the study's sample

\begin{tabular}{|c|c|c|}
\hline Category & Frequency & Percentage \\
\hline \multicolumn{3}{|l|}{ Gender } \\
\hline Male & 124 & 80.6 \\
\hline Female & 25 & 19.4 \\
\hline \multicolumn{3}{|l|}{ Education } \\
\hline Diploma or less & 30 & 23.3 \\
\hline Bachelor degree & 88 & 68.2 \\
\hline Masters degree or more & 11 & 8.5 \\
\hline \multicolumn{3}{|l|}{ Position } \\
\hline Manager & 28 & 21.7 \\
\hline Employee & 101 & 78.3 \\
\hline \multicolumn{3}{|l|}{ Experience } \\
\hline Less than 3 years & 43 & 33.3 \\
\hline 3 to 5 years & 49 & 38 \\
\hline 6 to 8 years & 30 & 23.3 \\
\hline 9 years or more & 7 & 5.4 \\
\hline
\end{tabular}




\subsection{Measures}

The questionnaires were used to collect information including: demographic characteristics, ERP implementation, employees' productivity, service quality and innovation from the selected sample. The measurement of the collected information is further explained below.

\subsubsection{Measures of ERP Successful Implementation}

ERP implementation was measured via two dimensions user satisfaction and organizational impact using five-point Likert-type scale ranging from 1 (strongly disagree) to 5 (strongly agree). Seven items assessed the respondents; degree of ERP implementation satisfaction (e.g. The ERP provides output and reports that I need). The coefficient alpha of this scale was 0.83 . In addition, organizational impact was measured by eight items (e.g. 'implementing the ERP system has helped to improve organizational-wide communication and sharing of information across the enterprise'). The coefficient alpha of this scale was 0.79 (Dezdar \& Sulaiman, 2011).

\subsubsection{Measures of Employees' Innovation}

Employees' innovative behavior was assessed using six items completed by each of the managers for each of their subordinates (e.g. 'generates creative ideas') via 5-point Likert-type scale ranging from 1 (strongly disagree) to 5 (strongly agree). The coefficient alpha was 0.75 .

\subsubsection{Measures of Service Quality}

Service quality was measured using three questions were adapted from (Durmuşoğlu \& Barczak, 2011). One question was 'the quality of the service compares well with other services that we have developed in the past'. These questions were assessed via 5-point Likert-type scale ranging from 1 (strongly disagree) to 5 (strongly agree). The coefficient alpha was 0.86 .

\subsubsection{Employees' Productivity}

Job productivity was measured by asking the question using the scale from 1 (poor) to 5 (excellent): 'what rating did you receive from your supervisor on your most recent performance appraisal on your current job this year?' According to Bright (2007) this is the most widely used question to measure the employee's productivity.

\subsection{Procedures}

At the outset of this research, the literature was reviewed in order to develop the data collection instrument to measure the study variables (see figure 1). Two questionnaires were developed; one for the managers and the other for the subordinates. The Study variables, except for the productivity, were measured from the subordinates' perspective. The productivity variable was evaluated from the managers' perspective. Face-to-face method was used to collect the data from both managers and employees. Two visits were conducted to administer and collect data from respondents. The respondents of this study participated voluntarily. A total of 129 questionnaires valid for analysis were retrieved. Subsequently, coding, data entry and analysis of data were conducted in order to describe the study sample characteristics, study variables and hypotheses testing.

\subsection{Data Analysis}

Two types of data analysis, Descriptive statistics including means and standard deviations and zero-order correlations between study variables were computed. Structural Equation Modeling (SEM) was used to assess the direct relationships among the study variables. AMOS version 16.0 was used to perform these analyses.

\section{Results}

\subsection{Descriptive Statistics}

Table 2 contains a summary of means, standard deviations, and pairwise correlation coefficients for all study variables. All measures exhibited suitable reliability coefficients (alpha coefficients varied between 0.74 and 0.845) based on criteria set by Nunnally (1978). 
Table 2. Descriptive statistics, alpha coefficients and intercorrelations between the study's variables

\begin{tabular}{|c|c|c|c|c|c|c|c|c|}
\hline & Mean & $\begin{array}{l}\text { Standard } \\
\text { Deviation }\end{array}$ & Alpha & 1 & 2 & 3 & 4 & 5 \\
\hline $\begin{array}{l}\text { Organization } \\
\text { impact }\end{array}$ & 4.39 & .446 & .845 & & & & & \\
\hline satisfaction & 4.17 & .608 & .813 & $.427 * *$ & & & & \\
\hline Productivity & 4.48 & .415 & .792 & $.448 * *$ & $.286^{* *}$ & & & \\
\hline Service Quality & 4.10 & .660 & .823 & $.483 * *$ & $.534 * *$ & $.428 * *$ & & \\
\hline Innovation & 4.11 & .673 & .743 & $.541 * *$ & $.510^{* *}$ & $.127 * *$ & $.402 * *$ & \\
\hline
\end{tabular}

Descriptive statistics for all variables are presented in table 2 including mean and standard deviation scores. The results of this study according to the analysis in table 2, shows that the employees' have thought that their companies have successfully implemented the ERP systems because the mean of the organizational impact and satisfaction were 4.39 and 4.17 respectively.

Furthermore, table 2 shows a preliminary analysis for evaluating the correlation between the independent and dependent variables of the study. Specifically, the results in table 2 indicated that there was a positive relationship between the organizational impact and the employees' productivity, service quality and innovation. The values ranged from ( 0.448 to 0.541$)$. In addition, table 2 showed a positive relationship between satisfaction and the employees' productivity, service quality and innovation. The values ranged from (0.286 to 0.510$)$.

\subsection{Hypothesis Testing}

Six criteria in this study were used to test the fit of this model (as summarized in table 3 and figure 2). The first one is the ratio of chi-square/degree of freedom. If chi-square/d.f. is less than 3 , it is considered as a good fit to the data. The second and third criteria were the GFI (goodness-of-fit index) and AGFI (adjusted goodness-of-fit index). The values of those two indices should be greater than 0.9. The forth one was the CFI (comparative fit index), which should be greater than 0.95 . The fifth was the RMR (root-mean-square residual). The smaller the RMR is, the better the fit of the model. A value of less than 0.05 indicates a close fit. The last index was the RMSEA (root mean square error of approximation). The RMSEA is acceptable when the value is less than 0.08 (Lee, Lee \&Wu, 2010).

Table 3. Result of GOF measures

\begin{tabular}{cccc}
\hline Goodness-of-Fit (GOF) Measure & $\begin{array}{c}\text { Conceptual } \\
\text { Model }\end{array}$ & Criterion & Reference \\
\hline$\chi^{2 / \text { degree of freedom }}$ & 2.83 & $<=3$ & Hair et. al, 2006 \\
GFI & 0.975 & $>0.8$ & $\begin{array}{c}\text { Etezadi-Amoli \& } \\
\text { Farhoomand, 1996 }\end{array}$ \\
AGFI & 0.874 & $>0.8$ & Etezadi-Amoli \& \\
CFI & 0.966 & $>0.95$ & Farhoomand, 1996 \\
RMR & 0.013 & $<0.05$ & Hair et. al, 2006 \\
RMSEA & 0.077 & $<0.08$ & Hair et. al, 2006 \\
\end{tabular}


The test of the conceptual model was carried out using the Amos analysis. The results of analysis are shown in table 4, which is about the direct effects between model path coefficients and variables. Table 4 shows that:

(1) Organization impact has a significant positive effect on productivity $(\beta=0.399, \mathrm{p}<0.05)$, so hypothesis 1 was supported; Service Quality $(\beta=0.312, \mathrm{p}<0.05)$, so hypothesis 2 was supported; innovation $(\beta=0.325, \mathrm{p}<$ 0.05), so hypothesis 3 was supported.

(2) Satisfaction has a significant positive effect on service quality $(\beta=0.401, \mathrm{p}<0.05)$, so Hypothesis 5 was supported; innovation $(\beta=0.342, \mathrm{p}<0.05)$, so Hypothesis 6 was supported. Whereas, satisfaction hasn't a significant effect on productivity $(\beta=0.116, \mathrm{p}>0.05)$, so hypothesis 4 wasn't supported.

In addition, two dimensions of ERP have explained each total variance, $21 \%$ for productivity, service quality $36 \%$ and innovation $32 \%$.

Table 4. Path analysis for the study's variables

\begin{tabular}{|c|c|c|c|c|c|}
\hline & Independent & Dependant & Coefficients & CR & $\begin{array}{c}\text { Support/ } \\
\text { nonsupport }\end{array}$ \\
\hline \multirow{6}{*}{ Path } & Organization impact & $\longrightarrow$ Productivity & .399 & 4.595 & support \\
\hline & Organization impact & $\longrightarrow$ Service Quality & .312 & 3.998 & support \\
\hline & Organization impact & $\longrightarrow$ Innovation & .325 & 4.028 & support \\
\hline & Satisfaction & $\longrightarrow$ Productivity & .116 & 1.333 & nonsupport \\
\hline & Satisfaction & $\longrightarrow$ Service Quality & .401 & 5.143 & support \\
\hline & Satisfaction & $\longrightarrow$ Innovation & .342 & 4.229 & support \\
\hline \multicolumn{3}{|c|}{ Explained variance proportion $\mathrm{R}^{2}$ of Productivity } & & 0.21 & \\
\hline \multicolumn{3}{|c|}{ Explained variance proportion $\mathrm{R}^{2}$ of Service Quality } & & 0.36 & \\
\hline \multicolumn{3}{|c|}{ Explained variance proportion $\mathrm{R}^{2}$ of Innovation } & & 0.32 & \\
\hline
\end{tabular}

Notes: 1. *: C.R. (critical ratio) .1.96; using a significant level of 0.05 , critical ratios that exceed 1.96 would be considered significant.

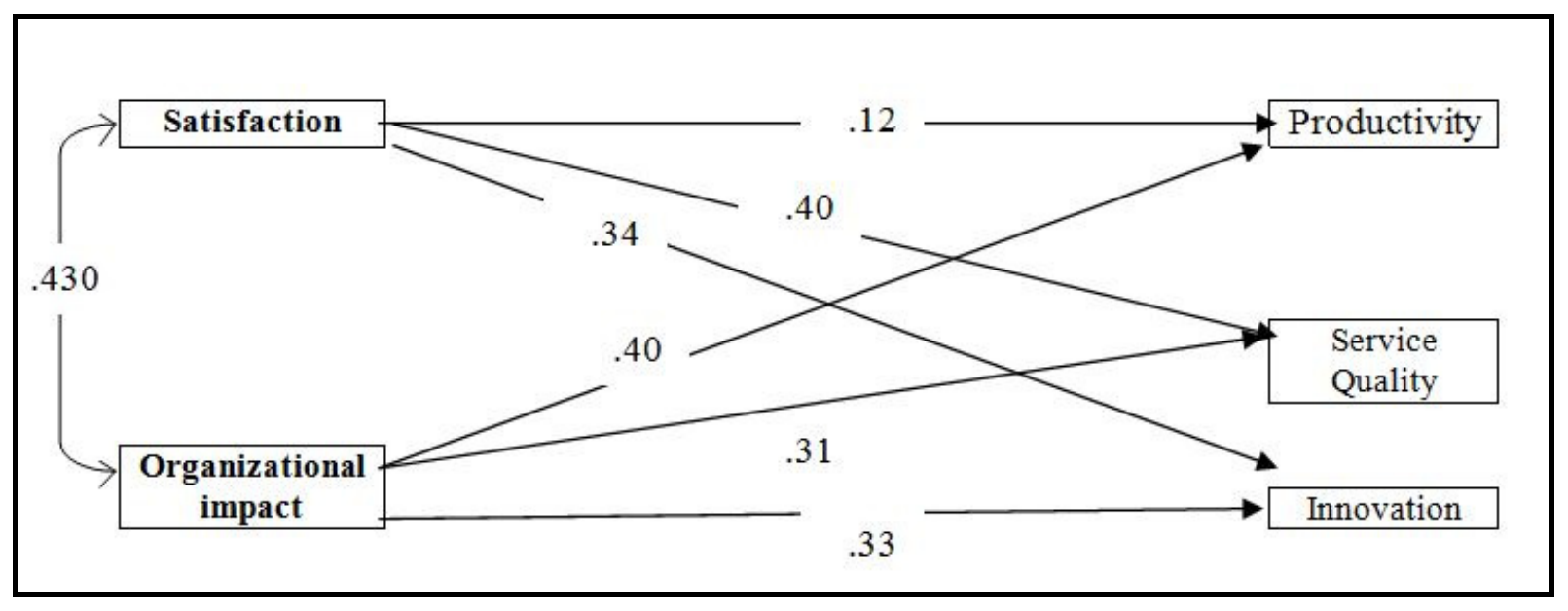

Figure 2. Significant path confidents (0.05 level) for ERP successful implementation and employees' productivity, service quality and innovation

\section{Discussion}

The objective of this study was to investigate the impact of ERP implementation on employees' innovative behavior, service quality and productivity. The results showed the path analysis of the construct of this study. Table 4 specifically indicated that there was a significant effect of the construct 'organizational impact' on productivity, innovation and service quality respectively. These results were consistent with the literature that 
explains such a positive relationship (Cooper (2003); Nurmilaakso (2009); Mjema et al. (2005); and Velcu (2010))

In respect to the impact of the other construct 'satisfaction', the results presented in table 4 showed a direct effect of this construct on service quality and innovation; whereas, satisfaction did not affect employees' productivity. Possibly this issue could be explained in terms of the lack of training that were given to employees. Another significant explanation could be that employees were still adapting to the change in business processes posed by such systems. Several researchers (Holland \& Light, 2001; Markus et al., 2000; O’Leary, 2000) stated that post to the initial ERP implementation, organizations might experience some losses in employees' productivity. Another interpretation to this result perhaps was due to the nature of ERP systems which actually tended to standardize processes within organizations. Therefore, in a highly competitive environment, employees at the organizational level might feel losing their competiveness and uniqueness and consequently affected their productivity when they worked with systems that imposed commonalities (Jones, Cline \& Ryan, 2006).

Kumar, Maheshwari \& Kumar (2003) outlined in their research study several reasons where employees' productivity could be affected negatively by the ERP implementation especially after the initial ERP implementation. Some of these reasons were: the miscommunication of new processes, inadequate user training, lack of support documentation, high user turnover and users took long period of time to cope with the new systems and processes.

\section{Conclusions, Recommendations and Further Research}

The results of this study showed the effect of the of ERP successful implementation antecedents on employees' productivity, service quality and innovation. As it was anticipated, organizational impact directly affected all of the dependent variables and this was supported by other research in this area. In addition, the satisfaction antecedent directly affected both service quality and innovation but surprisingly not the employee's productivity.

Based on the discussion (Section 4) of this study a number of recommendations and managerial implications could be outlined. In order to enhance the user's satisfaction as one of the constructs of ERP implementations, it is suggested that employees who use the ERP applications should be involved during the life cycle of ERP implementation. For example, employees should be able to select and modify the appropriate format of repots.

Furthermore, since employees would need time to adapt to the change imposed by the new technology, it would be very practical to develop a training course that identifies and explains all the necessary changes that would occur to the business processes inside the organization. Moreover, although ERP systems standardize processes inside organizations, fast learners and technology-adaptive employees should have the chance to be distinguished and rewarded based on this effort. Therefore, managers should support and encourage such employees with suitable ways and procedures for incentives and rewards.

However and as illustrated by Dezdar \& Sulaiman, (2011), that there is a lack of ERP research conducted in developing countries. Therefore, further research and comparison studies (in other developing countries) are required to study and reveal all the factors that are associated with ERP systems implementation in developing countries.

\section{References}

Alavi, M., \& Leidner, D. E. (2001). Knowledge management and knowledge management systems: conceptual foundations and research issues. MIS Quarterly, 25(1), 107-136. Retrieved from http://10.2307/3250961

Barsh, J. (2007). Innovation management: a conversation with Gary Hamel and Lowell Bryan. McKinsey Q.,3, $1-10$.

Beheshti, H. M. (2006). What managers should know about ERP/ERP II. Management Research News, 29(4), 184-193. Retrieved from http://10.1108/01409170610665040

Bosschaa, P., Coetzeea, R., Terblanchea, P., Gazendam, A., \& Isaac, S. (2006), Smart Factory: the challenges of open and low-cost ICT in the small manufacturing industry. South African Journal of Science, 102, 335-338.

Botta-Genoulaz, V., \& Millet, P. A. (2006). An Investigation into the use of ERP systems in the service sector. International Journal of Production Economics, 99, 202-221. Retrieved from http://10.1016/i.iipe.2004.12.015

Bright, L. (2007). Does person-organization fit mediate the relationship between public service motivation and the job performance of public employees? Review of Public Personnel Administration, 27(4), 361-79. 
Retrieved from http://10.1177/0734371X07307149

Caruso, D. (2009). Manufacturers: How ERP systems improve employee productivity. Retrieved from http://www.microsoft.com/dynamics/en/gulf/industries/erp-productivity.aspx

Chapman R., \& Hyland P. (2004). Complexity and learning behaviors in product innovation. Technovation, 24, 553-561. http://dx.doi.org/10.1016/S0166-4972(02)00121-9

Cooper, L.P. (2003). A research agenda to reduce risk in new product development through knowledge management: a practitioner perspective. Journal of Engineering and Technology Management, 20(1-2), 117-140. http://dx.doi.org/10.1016/S0923-4748(03)00007-9

Davenport, T. H. (2000). Mission critical: realizing the promise of enterprise systems. Harvard Business School Press, USA.

Davenport, T. H., De Long, D.W., \& Beers, M. C. (1998). Successful knowledge management projects. Sloan Management Review, 39(2), 43-57.

Dezdar, S., \& Sulaiman, A. (2009). Successful enterprise resource planning implementation: taxonomy of critical factors. Industrial Management \& Data Systems, 109(8), 1037-52. http://dx.doi.org/10.1108/02635570910991283

Dezdar, S., \& Sulaiman, A. (2011). The influence of organizational factors on successful ERP implementation. Management Decision, 49(6), 911-926. http://dx.doi.org/10.1108/00251741111143603

Doom, C., Milis, K., Poelmans, S., \& Bloemen, E. (2009). Critical success factors for ERP implementations in Belgian SMEs. Journal of Enterprise Information Management, 23(3), 378-406. http://dx.doi.org/10.1108/00251741111143603

Durmuşoğlu, S. S., \& Barczak, G. (2011). The use of information technology tools in new product development phases: Analysis of effects on new product innovativeness, quality, and market performance. Industrial Marketing Management, 40, 321-330. http://dx.doi.org/10.1016/j.indmarman.2010.08.009

Etezadi-Amoli, J., \& Farhoomand, A.F. (1996). A structural model of end user computing satisfaction and user performance. Information \& Management, 30(2), 65-73. http://dx.doi.org/10.1016/03787206(95)00052-6

Hair, J.F., Babin, W.C., Babin, B.J., Anderson, R.E., \& Tatham, R.L. (2006). Multivariate Data Analysis (6th ed). Englewood Cliffs, NJ: Prentice Hall.

Hamel G., \& Prahalad C.K. (1991). Corporate imagination and expeditionary marketing, Harv. Bus. Rev, 69, 81-92. http://dx.doi.org/10.1016/j.indmarman.2010.08.009

Holland, Light (2001). A stage maturity model for enterprise resource planning systems use. ACM SIGMIS Database, 32 (2). http://dx.doi.org/10.1145/506732.506737

Jacobson, S., Shepherd, J., D'Aquila, M., \& Carter, K. (2007). The ERP Market Sizing Report. Retrieved from http://www.gtm.sap.com/belux/solutions/business-suite/erp/pdf/AMR_ERP_Market_Sizing_2006-2011.pdf

Jones, M. C., Cline, M., \& Ryan, S. (2006). Exploring knowledge sharing in ERP implementation: An organizational culture framework. Decision Support Systems, 41(2), 411-434. http://dx.doi.org/10.1016/j.dss.2004.06.017

Kanter, R.M. (1988). When thousand flowers bloom. Research in Organizational Behavior, 10, 169-211. Retrieved from http://10.1177/0021886398342003

Kumar, V., Maheshwari, B., \& Kumar, U. (2003). An investigation of critical management issues in ERP implementation: empirical evidence from Canadian organizations. Technovation, 23, 793-807. http://dx.doi.org/10.1016/S0166-4972(02)00015-9

Laudon, K. C., \& LaudonJ. P. (2012). Management information systems: managing the digital firm, 12thEdition, Pearson Prentice-Hall.

Lee, F., Lee, T., \& Wu, W. (2010) .The relationship between human resource management practices, business strategy and firm performance: evidence from steel industry in Taiwan. The International Journal of Human Resource Management, 21 (9), 1351-1372. Retrieved from http://10.1080/09585192.2010.488428

Li, L., Su, Q., \& Chen, X. (2011). Ensuring supply chain quality performance through applying the SCOR model. International Journal of Production Research, 49(1), 33-57. http://dx.doi.org/10.1080/00207543.2010.508934 
Markus, M. L., Axlin, S., Petrie, D., \& Tanis C. (2000). Learning from adopters' experiences with ERP-successes and problems. Journal of Information Technology, 15, 245-265. Retrieved from http://10.1080/02683960010008944

McNurlin, B. C., \& Sprague, R. H. (2006). Information Systems Management In Practice. Pearson Prentice Hall.

Mjema E.A.M., Victor M.A.M., \& Mwinuka, M.S.M. (2005). Analysis of roles of IT on quality management. The TQM Magazine, 17(4), 364-75. http://dx.doi.org/10.1108/09544780510603206

Molla, A., \& Bhalla, A. (2006). Business transformation through ERP: a case study of an Asian Company. Journal of Information Technology Case and Application Research, 8(1), 34-54.

Nah, F., \& Lau, J. (2001). Critical factors for successful implementation of enterprise systems. Business Process Management Journal, 7(3), 285-296. http://dx.doi.org/10.1108/14637150110392782

Nunnally, J. C. (1978). Psychometric theory. New York: McGraw-Hill.

Nurmilaakso J. M. (2009). ICT solutions and labor productivity: evidence from firm-level data. Electron Commer Res, 9, 173-18. http://dx.doi.org/10.1007/s10660-009-9034-4

O'Leary, D. (2000). Enterprise resource planning systems: systems, life cycle, electronic commerce, and risk. New York: Cambridge University Press.

Rao, S. (2000). Enterprise resource planning: business needs and technologies. Industrial Management \& Data Systems, 1000(2). http://dx.doi.org/10.1108/02635570010286078

Rogers E. (1995). Diffusion of Innovations. Free Press, New York.

Soltani, E., Azadegan, A., Liao, Y., \& Phillips, P. (2011). Quality performance in a global supply chain: finding out the weak link. International Journal of Production Research, 49(1), 269-93. Retrieved from http://10.1080/00207543.2010.508955

Stratman, J. K., \& Roth, A.V. (2002). Enterprise resource planning (ERP) competence constructs: two-stage multi-item scale development and validation. Decision Sciences, 33(4), 601-28. Retrieved from $\mathrm{http} / / / 10.1111 / \mathrm{j} .1540-5915.2002 . \mathrm{tb} 01658 . \mathrm{x}$

Sumner, M. (2005). Enterprise Resource Planning. Pearson Education, Inc New Jersey.

Velcu, O. (2010). Strategic alignment of ERP implementation stages: An empirical investigation. Information \& Management, 47, 158-166. http://dx.doi.org/10.1016/j.im.2010.01.005

Yoo, D. K., Vonderembse, M. A., \& Ragu-Nathan, T. S. (2011). Knowledge quality: antecedents and consequence in project teams. Journal of Knowledge Management, 15(2), 329-343. http://dx.doi.org/10.1108/13673271111119727 